NASA Technical Memorandum 106585

\title{
Comparison of Life Theories for Rolling-Element Bearings
}

Erwin V. Zaretsky

National Aeronautics and Space Administration

Lewis Research Center

Cleveland, Ohio

Joseph V. Poplawski and Steven M. Peters

J.V. Poplawski \& Associates

Bethlehem, Pennsylvania

Prepared for the Annual Meeting sponsored by the Society of Tribologists and Lubrication Engineers Chicago, Illinois, May 14-19, 1995

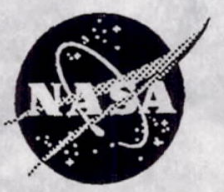

National Aeronautics and Space Administration

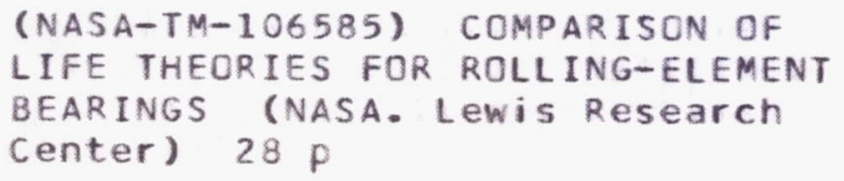

Unclas 


\title{
COMPARISON OF LIFE THEORIES FOR ROLLING-ELEMENT BEARINGS
}

\author{
Erwin V. Zaretsky ${ }^{*}$, Joseph V. Poplawski ${ }^{\dagger}$, \\ and Steven M. Peters ${ }^{\ddagger}$
}

\begin{abstract}
Nearly five decades have passed since G. Lundberg and A. Palmgren published their life theory in 1947 and 1952 and it was adopted as an ANSV/ABMA and ISO standard in 1950 and 1953. Subsequently, many variations and deviations from their life theory have been proposed, the most recent being that of E. Ioannides and T.A. Harris in 1985. This paper presents a critical analysis comparing the results of different life theories and discussing their implications in the design and analysis of rolling-element bearings. Variations in the stresslife relation and in the critical stress related to bearing life are discussed using stress fields obtained from three-dimensional, finite-element analysis of a ball in a nonconforming race under varying load. The results showed that for a ninth power stress-life exponent the Lundberg-Palmgren theory best predicts life as exhibited by most air-melted bearing steels. For a 12th power relation reflected by modern bearing steels, a Zaretsky-modified Weibull equation is superior. The assumption of a fatigue-limiting stress distorts the stress-life exponent and overpredicts life.
\end{abstract}

\section{SYMBOLS}

$\begin{array}{ll}A & \text { material constant } \\ a & \text { semimajor axis of contact ellipse, } \mathrm{m} \text { (in.) } \\ b & \text { semiminor axis of contact ellipse, } \mathrm{m} \text { (in.) } \\ C_{D} & \text { dynamic load capacity, } \mathrm{N} \text { (lbf) } \\ c & \text { critical shear stress-life exponent } \\ D & \text { ball diameter, } \mathrm{m} \text { (in.) } \\ e & \text { Weibull slope }\end{array}$

*Member STLE, NASA Lewis Research Center, Cleveland, OH.

${ }^{\dagger}$ Member STLE, J.V. Poplawski \& Assoc., Bethlehem, PA.

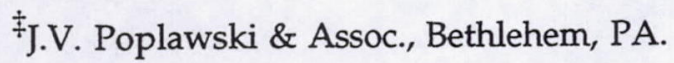




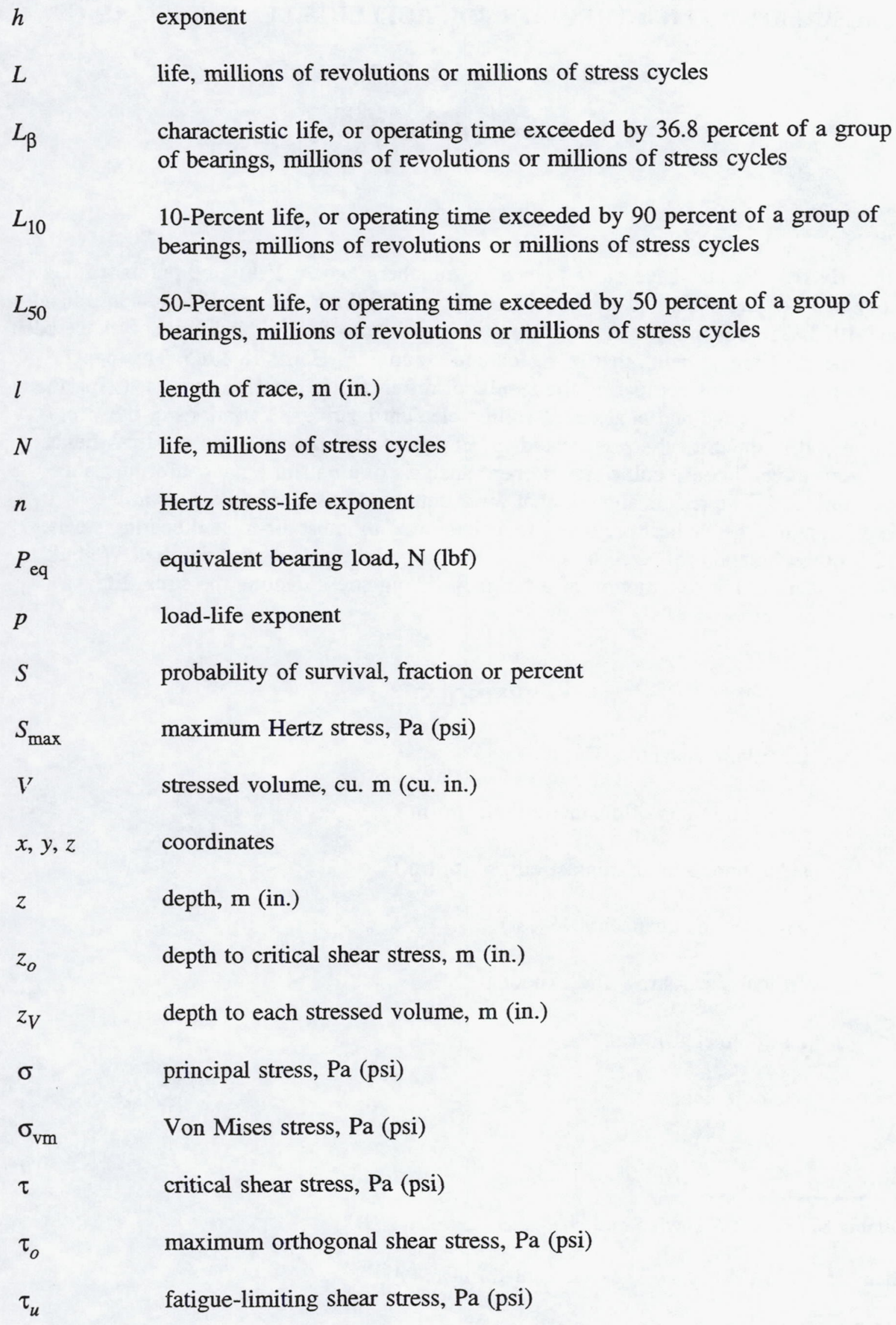




\section{Subscripts}

$\begin{array}{ll}i & \text { individual volume number } \\ \text { ref } & \text { reference state } \\ V & \text { elemental volume } \\ V R & \text { risk volume (Ref. 7) }\end{array}$

\section{INTRODUCTION}

Bearing fatigue life analysis is based on the initiation or first evidence of fatigue spalling on either a bearing race or a rolling element. This spalling phenomenon is time or cycle dependent. Generally, the spall begins in the region of maximum shear stresses, which is located below the contact surface, and propagates into a crack network. Failures other than those caused by classical rolling-element fatigue are considered avoidable if the bearing is properly designed, handled, installed, and lubricated and is not overloaded (Ref. 1). However, under low elastohydrodynamic (EHD) lubricant film conditions, rolling-element fatigue can be surface or near-surface initiated with the spall propagating into the region of maximum shear stresses.

If a number of apparently identical bearings are tested to fatigue at a specific load, there is a wide dispersion in life among the various bearings. For a group of 30 or more bearings the ratio of the longest to the shortest life may be 20 or more (Ref. 1).

The term "basic rating life," as used in bearing catalogs, usually means the fatigue life exceeded by 90 percent of the bearings or the time before which 10 percent of the bearings fail. This basic rating life is referred to as " $L_{10}$ life" (sometimes called $B_{10}$ life or 10-percent life). The 10-percent life is approximately one-seventh of the mean life, or MTBF (mean time between failures), for a normal life-dispersion curve (Ref. 1).

Weibull (Ref. 2) postulated that the dispersion in fatigue life for a homogeneous group of rolling-element bearings can be expressed according to the following relation:

$$
\ln \ln \frac{1}{S}=e \ln \frac{L}{L_{\beta}}
$$

Equation (1) relates the probability of survival $S$ and the life $L$ in millions of innerrace revolutions. When $\ln \ln (1 / S)$ is used as the ordinate and $\ln L$ as the abscissa, bearing fatigue data plot as a straight line. 
Weibull (Ref. 2) further stated that the probability of survival $S$ could be expressed as

$$
\ln \frac{1}{S} \sim \tau^{c} N^{e} V
$$

where $V$ is the volume representation of stress concentration referred to herein as "stressed volume," $\tau$ is the critical shear stress, and $c$ is a critical shear stress-life exponent where from Eq. (2)

$$
N \sim \tau^{-c l e}
$$

Lundberg and Palmgren (Ref. 3) extended the theoretical work of Weibull (Ref. 2) and showed that the probability of survival $S$ could be expressed as a power function of orthogonal shear stress $\tau_{o}$, life $N$, depth to maximum orthogonal shear stress $z_{o}$, and stressed volume $V$. That is,

$$
\ln \frac{1}{S} \sim \frac{\tau_{o}^{c} N^{e}}{z_{o}^{h}} V
$$

and where

$$
V=a l z_{o}
$$

Then

$$
\ln \frac{1}{S} \sim \frac{\tau_{o}^{c} N^{e} a l}{z_{o}^{h-1}}
$$

Lundberg and Palmgren based their life theory on subsurface-originated fatigue, where high EHD film conditions would exist. However, industry practice has evolved to use Lundberg-Palmgren theory for both high and low EHD film conditions. Hence, the theory is applicable to both surface- and subsurface-originated fatigue.

Lundberg and Palmgren (Ref. 3) obtained the following additional relation:

$$
L_{10}=\left[\frac{C_{D}}{P_{\mathrm{eq}}}\right]^{p}
$$

where $C_{D}$, the basic dynamic load capacity, is defined as the load that a bearing can carry for one million inner-race revolutions with a 90 -percent probability of survival, $P_{\text {eq }}$ is the 
equivalent bearing load, and $p$ is the load-life exponent. Endurance tests on ball bearings have shown that $p=3$ (Ref. 4). Most bearing manufacturers, the American National Standards Institute (ANSI)/Anti-Friction Bearing Manufacturers Association (AFBMA), and the International Organization for Standardization (ISO) have adopted this value of $p$ for ball bearings and 10/3 for roller bearings (Refs. 5 and 6). Substituting bearing geometry and Hertz stress for a given load and life into Eq. (6), with appropriate exponents, results in a value of $C_{D}$ for a given bearing.

Ioannides and Harris (Ref. 7) proposed a discrete-stressed-volume approach based on Lundberg-Palmgren (Ref. 3) for bearing life prediction. In their analysis they also proposed the concept of a fatigue limit. Zaretsky (Ref. 8) proposed a generalized Weibull-based methodology for structural fatigue life prediction that is also based on a discrete-stressedvolume approach. There are, however, distinct differences in approach between the method proposed by Zaretsky (Ref. 8) and that of Ioannides and Harris (Ref. 7).

Two stress-life exponents are referred to. The critical shear stress-life exponent $c$ is related to the Lundberg-Palmgren parameter cle (Eq. (3)) and applies if $V$ and $z_{o}$ are fixed. The Hertz stress-life exponent $n$ encompasses all the effects on life that arise when the Hertz stress is changed on a fixed geometry by varying the normal load. The contact or Hertz stress-life exponent $n$ (which is different from the critical shear stress-life exponent $c$ ) is related to the load-life exponent $p$ as follows:

$$
p=\frac{n}{3}
$$

To complicate matters, there appears to be an issue of what the value of $p$ should be for purposes of analysis. Work reported by Parker and Zaretsky (Ref. 9) suggests that for airmelt-processed steels, such as used by Lundberg and Palmgren (Ref. 3), the Hertz stress-life exponent $n$ is approximately 9 . However, for the cleaner and more recent vacuum-processed steels, $n \propto 12$.

Varying the Hertz stress-life exponent $n$ can significantly affect life predictions for bearings. Using $n=9$ results in a more conservative estimate of bearing life than using $n=$ 12. Also, the ratio of the predicted lives is a function of load and is directly related to $C_{D} / P_{\text {eq }}$. Hence, in the normal operating load envelope, life may be underpredicted by a factor of 20 when using the ANSI/AFBMA standards or a ninth power Hertz stress-life exponent $n$. A proper stress-life exponent then becomes more than of mere academic interest, since a designer requires a reliable analytic tool to predict bearing life and performance.

In view of the aforementioned discussion, the objectives of the work reported herein were (1) to evaluate and compare the various life theories for rolling-element bearings, specifically to point contacts; (2) to evaluate the effect of the critical shear stress-life exponent $c$ on the Hertz stress-life exponent $n$ and on bearing-life prediction; and (3) to determine what effect the presumption of a fatigue limit has on bearing life prediction. 


\section{HERTZ STRESS-LIFE RELATION}

The generally accepted relation between load and life in a rolling-element bearing is that life varies with the inverse cubic power of load for ball bearings (point contact) and with the inverse fourth power of load for roller bearings (line contact).

Because stress is proportional to the cube root of load for ball bearings, the load-life relation for ball bearings can be resolved into a stress-life relation, where life is inversely proportional to the maximum Hertz stress to the ninth power. This relation has been generally accepted by ball bearing manufacturers and users. There is at least one exception where a manufacturer has indicated that the life of ball bearings varies inversely with the fourth power of load (or 12th power of Hertz stress). Nevertheless, the inverse cubic load-life relation has been included in the ANSI/AFBMA standards for ball bearings (Ref. 5).

Later fatigue tests of ball bearings by several investigators tended to verify this inverse cubic relation. Styri (Ref. 10) presented data for two types of ball bearings. For one group of 6207 -size, deep-groove ball bearings under various radial loads from 3.5 to $17.3 \mathrm{kN}$ (775 to $3880 \mathrm{lbf}$ ), life was inversely proportional to load to the 3.3 power. Another group of 1207size, double-row, self-aligning bearings was tested such that the maximum Hertz stress at the outer-race-ball contact varied from 4.0 to $5.6 \mathrm{GPa}$ (580 to $810 \mathrm{ksi}$ ). Here it was found that life varied inversely with the ninth power of stress (or the third power of load). Cordiano et al. (Ref. 11) reported load-life data for 217-size, thrust-loaded ball bearings. The resultant Hertz stress-life exponents were 8.1, 9.6, and 12.6 for three lubricants, a water-glycol base, a phosphate ester base, and a phosphate ester, respectively. McKelvey and Moyer (Ref. 12) reported that, with four groups of AISI 4620, carburized-steel, crowned rollers (elliptical contact), fatigue life varied inversely with maximum Hertz stress to the eighth to ninth power. Maximum Hertz stress in these tests varied from 1.8 to $3.3 \mathrm{GPa}$ (262 to $478 \mathrm{ksi}$ ). Townsend et al. (Ref. 13) surface fatigue tested three groups of case-carburized, consumable-electrodevacuum-arc-remelted AISI $9310,8.89$-cm (3.5-in.) pitch diameter spur gears at maximum Hertz stresses of $1.5,1.7$, and $1.9 \mathrm{GPa}(222,248$, and $272 \mathrm{ksi})$. The gears were run at $10000 \mathrm{rpm}$ and $77^{\circ} \mathrm{C}\left(170^{\circ} \mathrm{F}\right)$. The lubricant was a superrefined naphthenic mineral oil with an additive package. The $L_{10}$ life varied inversely with stress to the 8.4 power, but the $L_{50}$ life varied inversely with stress to the 10.2 power. The average Hertz stress-life exponent $n$ was 9.3.

Several other investigators (Refs. 14 to 22) have reported data with bench-type, rolling-element fatigue testers, rather than with full-scale bearings or gears. The $L_{10}$ lives as a function of maximum Hertz stress for these data are shown in Figure 1, with the data summarized in Table 1. From the table the maximum Hertz stress for these data ranged from 3.7 to $9.0 \mathrm{GPa}$ (526 to $1300 \mathrm{ksi}$ ). With the exception of Greenert's work (Ref. 19) the stresslife exponents ranged from 8.4 to 12.4. The data are all for AISI 52100 and AISI M-50 steels (except for the data reported by Barwell and Scott (Ref. 14), who do not state the type of steel). At least two sets of data were for air-melted material, three were for vacuum-degassed material, and one was for vacuum-arc-remelted steel. The other references do not state the melting process. The stress-life exponents from Greenert (Ref. 19), ranging from 15 to 19 , are much higher than those from other published data. This lack of correlation is unexplained. 
Lorosch (Ref. 23) fatigue tested three groups of vacuum-degassed, 7205B-size, AISI 52100 inner races at maximum Hertz stresses of $2.6,2.8$, and $3.5 \mathrm{GPa}(370,406,500 \mathrm{ksi})$, respectively. Each group consisted of 20 races, for a total of 60. (It is assumed that all 60 races came from a single heat of material and were of the same hardness, but Lorosch (Ref. 23) does not state so in his paper.) After the test runs Lorosch examined cross sections of the races. He observed that only at the lowest stress, $2.6 \mathrm{GPa}$ (370 ksi), did no measurable plastic deformation occur. At the two higher stresses plastic deformations of different magnitudes were measured. Lorosch divided the races at the two higher stresses into groups according to these magnitudes. Group A included the races with the smaller deformations; and group B, the races with the larger deformations. The resultant stress-life exponent of groups A and B was 12. However, when E.V. Zaretsky reconstituted the data for groups A and B into a single group, designated group $\mathrm{AB}$, the stress-life exponent varied from 12 to 27 depending on the stress range over which the exponent was calculated. Lorosch (Ref. 23) did not calculate the stress reduction resulting from plastic deformation of the races, nor did he report on component hardness, hardness differential between the balls and races, and residual stresses induced during operation, all of which would also have affected his results. From these tests Lorosch (Ref. 23) concluded that "under low loads and with elastohydrodynamic lubrication there is no material fatigue, thus indicating that under such conditions bearing life is practically unlimited."

Zwirlein and Schlicht (Ref. 24), in a companion paper published concurrently with that of Lorosch (Ref. 23) and using the same 7205B-size bearing inner race data, state that "contact pressures less than $2.6 \mathrm{GPa}$ (370 ksi) do not lead to the formation of pitting within a foreseeable period. This corresponds to 'true endurance strength'." This observation would support the assumption by Ioannides and Harris (Ref. 7) of the existence of a "fatigue limit for bearing steels." However, this observation is not supported by rolling-element fatigue data in the open literature for stress levels under $2.6 \mathrm{GPa}(370 \mathrm{ksi})$ - such as those reported in References 25 to 29 , which exhibited classical rolling-element fatigue. In rotating machinery nearly all rolling-element bearings operate at a maximum Hertz stress less than $2.1 \mathrm{GPa}$ (300 ksi). Therefore, if Lorosch (Ref. 23) and Zwirlein and Schlicht (Ref. 24) were correct, no bearing in rotating machinery applications would fail by classical rolling-element fatigue.

To the authors' knowledge there are no reported laboratory-generated, full-scale bearing rolling-element fatigue data at stresses significantly below $2.1 \mathrm{GPa}(300 \mathrm{ksi})$ that would either establish or refute this presumption. However, Townsend et al. (Ref. 30) reported rolling-element fatigue tests for through-hardened spur gears made from vacuuminduction-melted, consumable-electrode-vacuum-arc-remelted (VIM-VAR) AISI M-50 steel run at a maximum Hertz stress of $1.7 \mathrm{GPa}(248 \mathrm{ksi})$. The AISI M-50 gears ran for at least five times the life of identical AISI 9310 gears and failed both by classical rolling-element fatigue and tooth bending fatigue. What is significant about these tests is that classical rollingelement fatigue is reported for a bearing steel (M-50) at stresses as low as $1.7 \mathrm{GPa}(248 \mathrm{ksi})$, the stress range in which most bearings operate. If there exists a fatigue limit for bearing steels, it certainly would have to be less than a maximum Hertz stress of $1.7 \mathrm{GPa}$ ( $248 \mathrm{ksi}$ ).

The explanation for the trend in the Lorosch (Ref. 23) and Zwirlein and Schlicht (Ref. 24) data is the inducement of compressive residual stresses in the AISI 52100 steel caused by the transformation of retained austenite into martensite during rolling-element 
cycling. These compressive residual stresses were reported by Zwirlein and Schlicht (Ref. 24). Compressive residual stresses reduce the effective magnitude of the maximum shear stresses caused by Hertzian loading. This lower stress results in longer bearing life and deviation from the Hertz stress-life exponent $n$ of 9 or 12 to a significantly higher value. Lorosch (Ref. 23) and Zwirlein and Schlicht (Ref. 24) extrapolated their data, leading them to conclude the existence of a fatigue-limiting stress rather than that induced compressive residual stresses had increased bearing life.

Lorosch (Ref. 23) performed another series of rolling-element fatigue experiments with 20 inner races, designated group $\mathrm{C}$, from the same heat as groups $\mathrm{A}$ and $\mathrm{B}$. He used a Rockwell hardness tester to make $0.1-\mathrm{mm}$-diameter indentations at four evenly spaced locations around the center of the race circumference. He divided group $\mathrm{C}$ into two 10bearing sets, which were tested at 2.6 and $2.8 \mathrm{GPa}$ (370 and $406 \mathrm{ksi}$ ), respectively. The $L_{10}$ lives for group $\mathrm{C}$ were significantly reduced from the group $\mathrm{AB}$ lives. These tests exhibited a 9.5 stress-life exponent. Because these indentations are analogous to wear debris denting during bearing operation, the results suggest that surface damage is another factor affecting the stress-life exponent.

\section{BALL-RACE MODEL}

To compare life theories and their variants, we selected a simple ball-race geometry model for evaluation. The model assumes a plurality of normally loaded $12.7-\mathrm{mm}$ (0.5-in.) diameter balls running in a linear, nonconforming grooved race having a groove radius of $6.6 \mathrm{~mm}(0.26 \mathrm{in}$.) and a length $l$. A schematic of the ball-race model is shown in Figure 2. The loads, stresses, and dimensions used for the ball-race model of Figure 2 are summarized in Table 2. The three-dimensional, finite-element analysis (FEA), geometry-for-the-gutter (Fig. 2) model used in the studies is shown in Figure 3. The model geometry takes advantage of the symmetric nature of the Hertzian contact for the case of no significant surface shear stresses. This model was expanded to encompass the full contact ellipse for our additional studies, which included different surface shear patterns and their influence on the related stress fields. However, those results are not reported as a part of this study. A full-race FEA geometry was also constructed. The full-race model will be used for studying the interaction of the centrifugal, axial clamping and press-fit stresses on the three-dimensional contact stress fields and their influence on bearing fatigue life.

The quarter section of the contact ellipse face was divided into approximately 162 elements. Element size ranged from $0.0991 \mathrm{~mm} \times 0.0330 \mathrm{~mm}(0.0039 \mathrm{in} . \times 0.0013 \mathrm{in}$. $)$ to $0.1278 \mathrm{~mm} \times 0.03175 \mathrm{~mm}(0.00503$ in. $\times 0.00125$ in.) depending on the Hertzian stress level. Element thickness in the depth direction was $0.0254 \mathrm{~mm}(0.0010 \mathrm{in}$.) until a depth $z / b$ of about 1.0. Beyond that depth the element thickness was gradually increased. A typical model contained approximately 3500 to 5900 solid isoparametric elements depending on the Hertz stress. The model for 2.4-GPa (350-ksi) Hertz stress had approximately 5800 elements and 7000 nodes, giving about 18000 degrees of freedom after applying constraint boundary conditions. The analysis was performed on a $386 / 33-\mathrm{MHz}$ personal computer with the COSMOS/M commercially available FEA software. 
We checked the FEA model results against calculated values by using classical Hertz contact stress theory. Figure 4 shows a comparison of the subsurface stresses at the center of the contact ellipse for 1.4-GPa (200-ksi) Hertzian stress. The FEA-predicted principal normal stresses and the in-plane shear stress $\tau_{45}$ agreed within 3 percent of theory over the Hertz stress range studied.

Figure 5 shows the three-dimensional Von Mises effective or equivalent stress field. A maximum stress of about $0.84 \mathrm{GPa}$ (122 ksi) occurred $0.114 \mathrm{~mm}$ ( $0.005 \mathrm{in}$.) below the surface for a 1.4-GPa (200-ksi) Hertz stress. Figure 6 shows that the in-plane shear stress $\tau_{45}$ on a plane cut through the center of the contact ellipse perpendicular to the rolling direction. The maximum shear stress of about $0.45 \mathrm{GPa}(66 \mathrm{ksi})$ also occurred $0.114 \mathrm{~mm}(0.005 \mathrm{in}$.) below the surface. Finally, Figure 7 shows the maximum orthogonal shear stress field acting in the $y-z$ plane. A mirror image of $\tau_{y z}$ also occurred at the forward half of the vertical symmetry axis but had the opposite sign (not shown). The largest orthogonal shear stress was $0.32 \mathrm{GPa}$ (46 ksi). It was the double amplitude of $\tau_{y z}$ on which Lundberg and Palmgren based their selection of that stress for their analysis.

Figures 5 to 7 were included to show the three stress distributions that have been discussed over the years as being the critical stress in determining bearing fatigue life. These three stresses are examined as the "stress of choice" within this paper.

The results of the FEA runs at the three Hertz stresses were saved as data bases to be used in evaluating the life theories examined in this paper. For purposes of analysis, only the life of the race will be considered at each load condition. The normal loads per ball are 623, 1617 , and $3333 \mathrm{~N}(140,364$, and $749 \mathrm{lbf})$ producing maximum Hertz stresses of 1.4, 1.9, and $2.4 \mathrm{GPa}(200,275$, and $350 \mathrm{ksi})$, respectively. The $L_{10}$ life at $2.4 \mathrm{GPa}(350 \mathrm{ksi})$ is normalized and assumed to be 1 . The normalized lives at each stress load are summarized in Table 2 for stress-life exponents $n$ of 9 and 12 and shown in Figure 8, where

$$
L_{10} \sim \frac{1}{S_{\max }^{n}}
$$

\section{RESULTS AND DISCUSSION}

\section{Weibull Equation}

The Lundberg-Palmgren theory (Ref. 3) is a variant of the Weibull theory of failure (Ref. 2). The genius of Lundberg and Palmgren was to realize its applicability to rollingelement bearings and to fit both bearing geometry and life data to the Weibull parameters. However, Lundberg and Palmgren do deviate from the Weibull equation by introducing the depth to the maximum critical shear stress $z_{0}$ shown in Eqs. (4) and (5), which they assumed to be the orthogonal shear stress. The rationale for introducing $z_{o}$ was, according to them, because "it is possible that changes in condition of the material also depend on the depth below the surface of the volume element considered. This assumption is necessary for the treatment of fatigue in rolling bearings." They go on to state, "Weibull's theory, however, is built on the assumption that the first crack leads to a break. The frequent examples of cracks 
which do not reach the surface seem to show that this assumption is not valid for fatigue in rolling bearings. Therefore, when setting up the life formulas consideration ought to be given to the fact that the probability of a fatigue break occurring must be taken to be dependent on the depth $z_{o}$ at which the most dangerous stress occurs" (Ref. 3).

Lundberg and Palmgren did not consider that in high-cycle fatigue crack initiation is probably over 95 percent of the life cycle and crack propagation is probably less than 5 percent of the life cycle. Accordingly, the life formula without $z_{o}$, as proposed by Weibull (Eq. (2)), may be applicable to bearing life prediction. Equation (2) can be written as follows:

$$
L_{10}=A\left(\frac{1}{V}\right)^{\frac{1}{e}}\left(\frac{1}{\tau}\right)^{\frac{c}{e}} \sim \frac{1}{S_{\max }^{n}}
$$

The factor $A$ is a material constant. From Hertz theory $V$ and $\tau$ can be expressed as a function of $S_{\max }$ where

$$
\begin{gathered}
\tau \sim S_{\max } \\
V \sim S_{\max }^{2}
\end{gathered}
$$

Substituting these values into Eq. (10) and solving for the exponents give

$$
\frac{-2-c}{e}=-n
$$

Experience has shown that the Weibull slope $e$ for most bearing fatigue data varies from 1 to 2. However, it has been accepted practice since Lundberg-Palmgren (Ref. 3) to assume this value to be 1.1. Experience has also shown the value of the Lundberg-Palmgren parameter $c / e$ to be 9 . As a result, $n$ would equal 10.81 .

Assuming $n$ of 9 and 12 , cle would equal 7.18 and 10.18 , respectively. Whereas cle $=$ 7.18 can be considered too low, $c l e=10.18$, although slightly higher than 9 , may be acceptable. Normalized values of the material constant $A$ for a Hertz stress-life exponent $n$ of 10.81 are given in Table 3. The calculated relative lives for each of the stresses are given in Table 4.

\section{Lundberg-Palmgren Equation}

The Lundberg-Palmgren theory has been discussed in some detail. A reading of Reference 3, however, does not make intuitively obvious their approach to bearing life prediction and the determination of their variables and exponents. Equation (4) can be rewritten as follows: 


$$
L_{10}=A\left(\frac{1}{V}\right)^{\frac{1}{e}}\left(\frac{1}{\tau_{o}}\right)^{\frac{c}{e}}\left(z_{o}\right)^{\frac{h}{e}} \sim \frac{1}{S_{\max }^{n}}
$$

As for $V$ and $\tau_{o}$ from Eqs. (11) and (12), $z_{o}$ can be expressed as a function of $S_{\max }$, where

$$
z_{o} \sim S_{\max }
$$

Substituting these values into Eq. (14) and solving for the exponents give

$$
\frac{-2-c+h}{e}=-n
$$

If it is assumed that $e=1.1$ and $n=9$, there are two unknowns to be solved for. A second equation is therefore necessary.

Lundberg and Palmgren (Ref. 3) showed rolling-element fatigue data $\left(L_{50}\right)$ from which a relation between ball diameter $D$ and life was empirically determined, where

$$
L \sim D^{5.4}
$$

From Hertz theory a relation for $V, \tau_{o}, z_{o}$, and $D$ may be obtained as follows:

$$
\begin{gathered}
\tau_{o} \sim D^{\frac{-2}{3}} \\
V \sim a z_{o} l \sim a b l \sim D^{\frac{2}{3}} D \sim D^{\frac{5}{3}} \\
z_{o} \sim D^{1 / 3}
\end{gathered}
$$

Substituting Eqs. (17) to (20) into Eq. (14) and solving for the exponents give

$$
\frac{-5+2 c+h}{3 e}=5.4
$$


Combining Eqs. (21) and (16) and substituting $e=1.1$ and $n=9$ yield $h=2.33$, or $h / e=2.1$ and $c / e=9.3$. These values, summarized in Table 3 , are those of the Lundberg-Palmgren equation (Ref. 3) and the ANSI/AFBMA standards (Ref. 5).

What Lundberg and Palmgren did not consider was the statistical variability of their data related to Eq. (16). From Hertz theory

$$
S_{\max } \sim D^{-2 / 3}
$$

Substituting Eq. (22) together with Eqs. (18) to (20) into Eq. (14) and solving for the exponents give

$$
\frac{-5+2 c+h}{3 e}=\frac{2 n}{3}
$$

Letting $e=1.1$ and $n=9$ yields $h=3$, or $h / e=2.7$ and $c / e=9.9$. Although $c / e=9.9$ is slightly high, it is acceptable. If it is assumed that $n=12$, Eqs. (16) and (23) yield $h / e=2.7$ and $c / e=12.91$. From experience this $c / e$ is too high and not realistic.

\section{Ioannides-Harris Equation}

Ioannides and Harris (Ref. 7), using Weibull (Ref. 2) and Lundberg and Palmgren (Ref. 3), introduced a fatigue-limiting stress and integrated the computed life of elemental stress volumes to predict bearing life. Their equation, which relates to each elemental volume, is as follows:

$$
\ln \frac{1}{s} \sim N^{e} \int_{V R} \frac{\left(\tau_{o}-\tau_{u}\right)^{c}}{z^{h}} d V
$$

The equation is similar to that of Lundberg and Palmgren (Eq. (4)) except for the introduction of a fatigue-limiting stress $\tau_{u}$. Equation (24) can be rewritten to represent each individual stressed volume as follows:

$$
L_{V}=A\left(\frac{1}{V_{V}}\right)^{\frac{1}{e}}\left(\frac{1}{\tau_{o}-\tau_{u}}\right)^{\frac{c}{e}}\left(z_{V}\right)^{\frac{h}{e}}
$$

The three-dimensional FEA model data base previously discussed contains the elemental volumes and associated stresses. An elemental reference volume is required to be selected as well as a reference stress and reference depth. These reference points can be taken as the volume comprising the maximum critical shear stress and the depth to this volume. Equation (25) can be rewritten as follows: 


$$
\begin{aligned}
{\left[\frac{L_{i}}{L_{\mathrm{ref}}}\right]=} & {\left[\frac{V_{\mathrm{ref}}}{V_{i}}\right]^{\frac{1}{e}}\left[\frac{\left(\tau_{o}-\tau_{u}\right)_{\mathrm{ref}}}{\left(\tau_{o}-\tau_{u}\right)_{i}}\right]^{\frac{e}{e}}\left[\frac{z_{i}}{z_{\mathrm{ref}}}\right]^{\frac{h}{e}} } \\
& \left(\frac{1}{L}\right)^{e}=\sum_{i=1}^{n}\left(\frac{1}{L_{i}}\right)^{e}
\end{aligned}
$$

Equation (26) is identical to the Lundberg-Palmgren Eq. (14) except for the fatigue-limiting stress $\tau_{u}$. Values of $e=1.1, c / e=9.3$, and $h / e=2.1$ for the ball-race model of Figure 2 as well as a reference volume and shear stress $\tau_{45}$ of $104 \times 10^{-15} \mathrm{~m}^{3}\left(6.33 \times 10^{-9}\right.$ in. $\left.^{3}\right)$ and 0.77 $\mathrm{GPa}(111 \mathrm{ksi})$, respectively, were assumed for the Ioannides-Harris Eq. (26). Values of $\tau_{u}=$ $0.21 \mathrm{GPa}(30 \mathrm{ksi})$ for $\tau_{o}$ and $\tau_{45}$ and $0.35 \mathrm{GPa}(50 \mathrm{ksi})$ for $\sigma_{\mathrm{vm}}$ were also assumed. The relative life calculations are summarized in Table 4 and compared with the previous calculations for the Weibull Eq. (10) and the Lundberg-Palmgren Eq. (14). As might be expected, the relative life values at $1.4 \mathrm{GPa}(200 \mathrm{ksi})$ are extremely high with this approach, in contrast to what would be expected. If the apparent values of the Hertz stress-life exponent $n$ were 19.6 when the orthogonal shear stress was used, 16.8 when the maximum shear stress was used, and 15.1 when the Von Mises stress was used, only two sets of data in the literature (Refs. 19, 23, and 24) would support this analysis.

\section{Zaretsky Equation}

Both the Weibull and Lundberg-Palmgren equations relate the critical shear stress-life exponent $c$ to the Weibull slope $e$. The Lundberg-Palmgren parameter cle thus becomes, in essence, the effective critical shear stress-life exponent, implying that the critical shear stresslife exponent depends on bearing life scatter or dispersion. A search of the literature for a wide variety of materials and for non-rolling-element fatigue reveals that most stress-life exponents vary from 6 to 12. The exponent appears to be independent of scatter or dispersion in the data. Hence, Zaretsky (Ref. 31) has rewritten the Weibull equation to reflect that observation by making the exponent $c$ independent of the Weibull slope $e$, where

$$
\ln \frac{1}{S} \sim \tau^{c e} N^{e} V
$$

Equation (28) differs from the Weibull Eq. (2) and the Lundberg-Palmgren Eq. (4) only in the exponent of the stress $\tau$. Only for $e=1$ do the two reflect the same power relation. Equation (28) differs from Lundberg-Palmgren further in that it does not recognize the effect of stress depth $z_{0}$. In addition, the Zaretsky model differs from Lundberg-Palmgren conceptually because it makes survival probabilities dependent on local stress pointwise in the stressed volume as does Ioannides-Harris (Ref. 7), whereas Lundberg-Palmgren used only one critical stress. Equation (28) can be written like Eq. (10),

$$
L_{10}=A\left(\frac{1}{V}\right)^{\frac{1}{e}}\left(\frac{1}{\tau}\right)^{c}
$$


Equation (29) has a life-stressed-volume exponent dependent on data dispersion or cumulative distribution and a critical stress exponent independent of data dispersion or Weibull slope.

Zaretsky, like Ioannides and Harris (Ref. 7), integrates the complete life of elemental stressed volumes as follows:

$$
\ln \frac{1}{S} \sim N^{e} \int_{V} \tau^{c e} d V
$$

As with Ioannides and Harris (Ref. 7) an elemental reference volume is required. Equation (29) is rewritten as follows:

$$
\left[\frac{L_{i}}{L_{\mathrm{ref}}}\right]=\left[\frac{V_{\mathrm{ref}}}{V_{i}}\right]^{1 / e}\left[\frac{\tau_{\mathrm{ref}}}{\tau_{i}}\right]^{c}
$$

The lives of the individual stressed elements are summarized in accordance with Eq. (27).

Using the same finite-element analysis as used for the Ioannides-Harris Eq. (26) and assuming that $c=9$ and $e=1.1$, the relative lives at each stress level were calculated and are summarized in Table 4 on the basis of maximum shear stress $\tau_{45}$ and the Von Mises stress $\sigma_{\mathrm{vm}}$. The apparent Hertz stress-life exponent $n$ was 10.8 for the maximum shear stress and 11.1 for the Von Mises shear stress. Both values coincide with experimental values in the literature (Table 1). However, the same stress-life exponent is obtained if the Weibull Eq. (10) is used without a finite-element analysis.

Although Zaretsky (Ref. 31) does not propose a fatigue-limiting stress, he does not exclude that concept either. However, his approach is entirely different from that of Ioannides and Harris (Ref. 7). For critical stresses less than the fatigue-limiting stress, the life for the elemental stressed volume is assumed to be infinite. With this assumption and for the same fatigue-limiting stresses used previously with the Ioannides-Harris Eq. (26), the lives at the three stress levels were recalculated. The resultant lives were no different from those shown under the Zaretsky equation column in Table 4 . However, if $\left(\tau_{i}-\tau_{u}\right)$ and $\left(\tau_{\text {ref }}-\tau_{u}\right)$ are substituted for $\tau_{i}$ and $\tau_{\text {ref }}$ in Eq. (31), the values of the stress-life exponent $n$ approach those of Ioannides and Harris (Ref. 7) shown in Table 4.

\section{MATERIAL CONSTANT}

The material constant $A$ in each life equation allows the equation to be matched with existing data, as Lundberg and Palmgren (Ref. 3) did in their original work. Because there are no data for the ball-race model of Figure 2, it is possible to normalize the material constant for a normalized $L_{10}$ life of 1 at a maximum Hertz stress $S_{\max }$ of $2.4 \mathrm{GPa}$ (350 ksi). These normalized values are summarized and compared in Table 3 for each life analysis. The units for $A$ will differ depending on what equation it is related to. The race length $l$ is factored out of the stressed volume and is shown as part of the material constant. For finite-element 
analyses the length of the unit volume in the rolling direction has been factored into the material constant.

\section{CONCLUDING COMMENTS}

The comparisons presented herein are perhaps the first time a qualitative comparison has been made between the various theories and approaches to predicting bearing life. No attempt was made to factor into the life equation other variables covered by STLE Life Factors for Rolling Bearings (Ref. 32). However, it is noteworthy to consider the effect of residual stresses and hoop stresses on rolling-element fatigue life. The Lundberg-Palmgren equation uses orthogonal shear stress as the critical shear stress. This stress would not be significantly affected either by hoop or residual stresses below the contact surface. The two dominant stresses that must be considered are the shear stress $\tau_{45}$ and the Von Mises stress $\sigma_{\mathrm{vm}}$. Our calculations strongly suggest that the Von Mises stress may more accurately reflect the magnitude of change in life with hoop stress and that both the Von Mises and $\tau_{45}$ shear stresses may proportionately reflect the effect of residual stress.

We provided a finite-element method that permits the practical implementation, with accessible computer resources, of a life model which integrates survival probabilities over the stressed volume for several suggested expressions for the survival probability of a volume element, such as those of Lundberg-Palmgren, Ioannides-Harris, or Zaretsky. Using this method it should now be possible to more accurately assess the effect of surface traction, residual stress, and hoop stress on bearing life and reliability.

In our opinion there may be strong justification that this is the time to reexamine the Lundberg-Palmgren equation. The equation has served the manufacturer, designer, and user of bearings well. However, even with STLE life factors the life predictions are conservative. We believe that the approach of Zaretsky (Ref. 31), based on a modified Weibull equation, best reflects the modern data base for bearing steels. However, a significant effort would be required to change existing bearing design computer codes and the ANSI/AFBMA and ISO standards in order to make any changes practical to the user community.

\section{SUMMARY OF RESULTS}

A critical analysis was presented comparing the results of different life theories and discussing their implications in the design and analysis of rolling-element bearings. The following results were obtained:

1. For an inverse ninth power relation between life and maximum Hertz stress, the Lundberg-Palmgren theory qualitatively predicts life best. However, for an inverse 12th power relation between life and maximum Hertz stress, a Zaretsky-modified Weibull equation is superior.

2. The Ioannides-Harris-modified, Lundberg-Palmgren equation based on a "fatiguelimiting stress" significantly overpredicts life. Analysis implies an inverse life-maximum Hertz stress exponent as high as 19.6 for a fatigue-limiting stress of $0.21 \mathrm{GPa}(30 \mathrm{ksi})$. 
3. Using a fatigue-limiting stress coupled with a finite-element analysis while assuming that those elements being stressed below the fatigue limit have infinite life does not affect life prediction. However, subtracting a fatigue-limiting stress from each elemental stress distorts the life-maximum Hertz stress relation, producing unreasonably high predictions of life.

\section{REFERENCES}

1. Boness, R.J., Crecelius, W.J., Ironside, W.R., Moyer, C.A., Pfaffenberger, E.E., and Poplawski, J.V., "Current Practice," STLE Life Factors for Rolling Bearings, E.V. Zaretsky, ed., STLE SP-34, Society of Tribologists and Lubrication Engineers, Park Ridge, IL, 1992, pp. 1-45.

2. Weibull, W., "The Phenomenon of Rupture in Solids," Ingeniors Vetenskaps Akademien, No. 153, 1939.

3. Lundberg, G. and Palmgren, A., "Dynamic Capacity of Rolling Bearings," Acta Polytechnica, Mechanical Engineering Series, Vol. 1, No. 3, Stockholm, 1947.

4. Lieblein, J. and Zelen, M., "Statistical Investigation of the Fatigue Life of Deep-Groove Ball Bearings," Journal of Research of the National Bureau of Standards, Vol. 57, No. 5, 1956.

5. Anon., "Load Ratings and Fatigue Life for Ball Bearings," ANSI/AFBMA 9-1990, The Anti-Friction Bearing Manufacturers Association, Washington, DC, 1990.

6. Anon., "Load Ratings and Fatigue Life for Roller Bearings," ANSI/AFBMA 11-1990, The Anti-Friction Bearing Manufacturers Association, Washington, DC, 1990.

7. Ioannides, E. and Harris, T.A., "A New Fatigue Life Model for Rolling Bearings," Journal of Tribology, Vol. 107, No. 3, 1985, pp. 367-378.

8. Zaretsky, E.V., "Fatigue Criterion to System Design, Life and Reliability," Journal of Propulsion and Power, Vol. 3, No. 1, 1987, pp. 76-83.

9. Parker, R.J. and Zaretsky, E.V., "Reevaluation of the Stress Life Relation in RollingElement Bearings," NASA TN D-6745, 1972.

10. Styri, H., "Fatigue Strength of Ball Bearing Races and Heat Treated 52100 Steel Specimens," Proceedings of American Society for Testing and Materials, Vol. 51, 1951, pp. $682-700$.

11. Cordiano, H.V., Cochran, E.P., Jr., and Wolp, R.J., "A Study of Combustion Resistant Hydraulic Fluids as Ball Bearing Lubricants," Lubrication Engineering, Vol. 12, No. 4, 1956, pp. 261-266. 
12. McKelvey, R.E. and Moyer, C.A., "The Relation Between Critical Maximum Compressive Stress and Fatigue Life Under Rolling Contact," Paper 1, Presented at the Institution of Mechanical Engineers Symposium on Fatigue in Rolling Contact, Mar. 28, 1963.

13. Townsend, D.P., Coy, J.J., and Zaretsky, E.V., "Experimental and Analytical Load-Life Relation for AISI 9310 Steel Spur Gears," Journal of Mechanical Design, Vol. 100, No. 1,1978 , pp. 54-60.

14. Barwell, F.T. and Scott, D., "Effect of Lubricant on Pitting Failure of Ball Bearings," Engineering, Vol. 182, No. 4713, 1956, pp. 9-12.

15. Butler, R. H. and Carter, T.L., "Stress-Life Relation of the Rolling-Contact Fatigue Spin Rig," NACA TN 3930, 1957.

16. Baughman, R.A., "Experimental Laboratory Studies of Bearing Fatigue," ASME Paper 58-A-235, 1958.

17. Scott, D., "Lubricants at Higher Temperatures: Assessing the Effects on Ball Bearing Failures," Engineering, Vol. 185, No. 4811, 1958, pp. 660-662.

18. Utsmi, T. and Okamoto, J., "Effect of Surface Roughness on the Rolling Fatigue Life of Bearing Steels," Journal of Japan Society of Lubrication Engineers, Vol. 5, No. 5, 1960, pp. 291-296.

19. Greenert, W.J., "The Toroid Contact Roller Test as Applied to the Study of Bearing Materials," Journal of Basic Engineering, Vol. 84, No. 1, 1962, pp. 181-191.

20. Valori, R.R., Sibley, L.B., and Tallian, T.E., "Elastohydrodynamic Film Effects on the Load-Life Behavior of Rolling Contacts," ASME Paper 65-LUBS-11, 1965.

21. Schatzberg, P. and Felsen, I.M., "Influence of Water on Fatigue-Failure Location and Surface Alteration During Rolling-Contact Lubrication," Journal of Lubrication Technology, Vol. 91, No. 2, 1969, pp. 301-307.

22. Zaretsky, E.V. and Parker, R.J., Discussion to Paper "On Competing Failure Modes in Rolling Contact," by T.E. Tallian, ASLE Transactions, Vol. 10, No. 4, 1967, pp. 436-437.

23. Lorosch, H.K., "Influence of Load on the Magnitude of the Life Exponent for Rolling Bearings," Rolling Contact Fatigue Testing of Bearing Steels, J.J.C. Hoo, ed., ASTM STP-771, American Society for Testing and Materials, Philadelphia, PA, 1982, pp. 275-292. 
24. Zwirlein, O. and Schlicht, H., "Rolling Contact Fatigue Mechanisms-Accelerated Testing Versus Field Performance," Rolling Contact Fatigue Testing of Bearing Steels, J.J.C. Hoo, ed., ASTM STP-771, American Society for Testing and Materials, Philadelphia, PA, 1982, pp. 358-379.

25. Bamberger, E.N., Zaretsky, E.V., and Signer, H., "Endurance and Failure Characteristics of Main-Shaft Jet Engine Bearing at $3 \times 10^{6} \mathrm{DN}$," Journal of Lubrication Technology, Vol. 98 , No. 4, 1976, pp. 580-585.

26. Parker, R.J., Zaretsky, E.V., and Bamberger, E.N., "Evaluation of Load-Life Relation With Ball Bearings at 500 'F," Journal of Lubrication Technology, Vol. 96, No. 3, 1974, pp. 391-397.

27. Bamberger, E.N. and Zaretsky, E.V., "Fatigue Lives at $600{ }^{\circ} \mathrm{F}$ of 120 -Millimeter-Bore Ball Bearings of AISI M-50, AISI, M-1, and WB-49 Steels," NASA TN D-6156, 1971.

28. Bamberger, E.N., Zaretsky, E.V., and Anderson, W.J., "Effect of Three Advanced Lubricants on High-Temperature Bearing Life," Journal of Lubrication Technology, Vol. 92, No. 1, 1970, pp. 23-33.

29. Zaretsky, E.V., Anderson, W.J., and Bamberger, E.N., "Rolling-Element Bearing Life From 400 to 600 'F," NASA TN D-5002, 1969.

30. Townsend, D.P., Bamberger, E.N., and Zaretsky, E.V., "A Life Study of Ausforged, Standard Forged, and Standard Machined AISI M-50 Spur Gears," Journal of Lubrication Technology, Vol. 98, No. 3, 1976, pp. 418-425.

31. Zaretsky, E.V., "Design for Life, Plan for Death," Machine Design, Vol. 66, No. 15 , Aug. 8, 1994, pp. 55-59.

32. Zaretsky, E.V., "Application of Life Factors," STLE Life Factors for Rolling Bearings, E.V. Zaretsky, ed., STLE SP-34, Society of Tribologists and Lubrication Engineers, Park Ridge, IL, 1992, pp. 233-298. 
TABLE 1.-PUBLISHED BENCH-TYPE RIG ROLLING-ELEMENT FATIGUE DATA RELATED TO STRESS-LIFE EFFECTS [From Parker and Zaretsky (Ref. 9).]

\begin{tabular}{|c|c|c|c|c|c|c|c|c|c|}
\hline \multirow{2}{*}{$\begin{array}{l}\text { Number } \\
\text { from } \\
\text { Fig. } 1\end{array}$} & \multirow[t]{2}{*}{ Reference } & \multicolumn{2}{|c|}{ Material } & \multirow[t]{2}{*}{ Lubricant } & \multirow{2}{*}{$\begin{array}{l}\text { Load range, } \\
\mathrm{kg}\end{array}$} & \multirow{2}{*}{$\begin{array}{l}\text { Maximum Hertz } \\
\text { stress range, } \\
\text { GPa (ksi) }\end{array}$} & \multirow{2}{*}{$\begin{array}{l}\text { Load- } \\
\text { life } \\
\text { exponent }\end{array}$} & \multirow{2}{*}{$\begin{array}{l}\text { Stress- } \\
\text { life } \\
\text { exponent }\end{array}$} & \multirow[t]{2}{*}{ Test type } \\
\hline & & Type & $\begin{array}{l}\text { Melting } \\
\text { process }\end{array}$ & & & & & & \\
\hline 1 & $\begin{array}{l}\text { Barwell and } \\
\text { Scott (Ref. 14) }\end{array}$ & - & (a) & Mineral oil & 200 to 600 & $\mathrm{~b}_{4.5}$ to $6.6\left({ }^{\mathrm{b}} 660\right.$ to 950$)$ & 2.8 & 8.4 & Four ball \\
\hline 2 & $\begin{array}{l}\text { Butler and Carter } \\
\text { (Ref. 15) }\end{array}$ & AISI 52100 & Air melt & $\begin{array}{l}\text { SAE } 10 \\
\text { mineral oil }\end{array}$ & 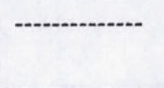 & 4.1 to 5.2 (600 to 750 ) & 3.5 & 10.4 & Spin rig \\
\hline 3 & $\begin{array}{l}\text { Butler and Carter } \\
\text { (Ref. 15) }\end{array}$ & $\begin{array}{l}\text { MV-1 } \\
\text { (AISI M-50) }\end{array}$ & Air melt & $\begin{array}{l}\text { SAE } 10 \\
\text { mineral oil }\end{array}$ & --..--...-..- & 4.1 to 5.2 (600 to 750$)$ & 3.2 & 9.7 & Spin rig \\
\hline 4 & $\begin{array}{l}\text { Baughman } \\
\text { (Ref. 16) }\end{array}$ & $\begin{array}{l}\text { MV-1 } \\
\text { (AISI M-50) }\end{array}$ & (a) & MIL-L-7808 & - n & 4.4 to 5.4 ( 640 to 777 ) & 3.2 & 9.7 & $\begin{array}{l}\text { Rolling- } \\
\text { contact rig }\end{array}$ \\
\hline 5 & Scott (Ref. 17) & $\begin{array}{l}\text { EN-31(AISI } \\
52100)\end{array}$ & (a) & Diester & 400 to 600 & ${ }^{\mathrm{b}} 5.7$ to 6.6 (830 to 950$)$ & 3.6 & 10.8 & Four ball \\
\hline 6 & $\begin{array}{l}\text { Ulemi and } \\
\text { Okomoto } \\
\text { (Ref. 18) }\end{array}$ & AISI 52100 & (a) & \#60 Spindle oil & -.n-n-n & 3.7 to 5.1 ( 526 to 730 ) & $c_{2.8}$ & ${ }^{c} 8.5$ & $\begin{array}{l}\text { Crowned } \\
\text { disk }\end{array}$ \\
\hline 7 & $\begin{array}{l}\text { Greenert } \\
\text { (Ref. 19) }\end{array}$ & AISI 52100 & (a) & $\begin{array}{l}\text { Navy } 2190 \text { TEP } \\
\text { lubricating oil }\end{array}$ & (2) & 5.8 to 6.1 ( 840 to 890 ) & $c_{5}$ to 6.3 & ${ }^{c} 15$ to 19 & Toroids \\
\hline 8 & $\begin{array}{l}\text { Valori et al. } \\
\text { (Ref. 20) }\end{array}$ & AISI 52100 & $\begin{array}{l}\text { Vacuum-arc } \\
\text { remelted }\end{array}$ & Mineral oil & 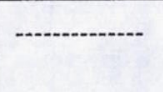 & 4.2 to 5.5 ( 610 to 800$)$ & $\mathrm{d}_{4.1}$ & $d_{12.4}$ & Four ball \\
\hline 9 & $\begin{array}{l}\text { Schatzberg and } \\
\text { Felsen (Ref. 21) }\end{array}$ & AISI 52100 & $\begin{array}{l}\text { Vacuum } \\
\text { degassed }\end{array}$ & Squalene & - & 6.4 to 9.0 (925 to 1300$)$ & 3.8 & 11.5 & Four ball \\
\hline 10 & $\begin{array}{l}\text { Schatzberg and } \\
\text { Felsen (Ref. 21) }\end{array}$ & AISI 52100 & $\begin{array}{l}\text { Vacuum } \\
\text { degassed }\end{array}$ & $\begin{array}{l}\text { Squalene }+ \\
100 \text { ppm } \mathrm{H}_{2} \mathrm{O}\end{array}$ & -........- & 6.4 to 9.0 (925 to 1300$)$ & 3.9 & 11.7 & Four ball \\
\hline 11 & $\begin{array}{l}\text { Parker and } \\
\text { Zaretsky (Ref. 9) }\end{array}$ & AISI 52100 & $\begin{array}{l}\text { Vacuum } \\
\text { degassed }\end{array}$ & $\begin{array}{l}\text { Paraffinic } \\
\text { mineral oil }\end{array}$ & -........... & 4.5 to 6.0 ( 650 to 857 ) & 4 & 12 & Five ball \\
\hline
\end{tabular}

${ }^{\mathrm{a}}$ Melting process not reported.

${ }^{b}$ Approximate stress range, not reported by authors of reference.

${ }^{c}$ Estimated, not reported by authors of reference.

${ }^{\mathrm{d}}$ Reanalyzed by Zaretsky and Parker (Ref. 22). 
TABLE 2.-SUMMARY OF STRESSES, HERTZIAN DIMENSIONS, AND RELATIVE LIVES FOR

BALL-RACE MODEL OF FIGURE 2

[Ball diameter, $12.7 \mathrm{~mm}$ (0.5 in.); race-groove radius, $6.6 \mathrm{~mm}$ (0.026 in.).]

\begin{tabular}{|c|c|c|c|}
\hline \multirow[t]{2}{*}{ Parameter } & \multicolumn{3}{|c|}{ Normal ball load, $\mathrm{N}$ (lbf) } \\
\hline & $623(140)$ & $1617(364)$ & $3333(749)$ \\
\hline Maximum Hertz stress, GPa (ksi) & $1.4(200)$ & $1.9(275)$ & $2.4(350)$ \\
\hline \multicolumn{4}{|l|}{ Hertzian contact ellipse, $\mathrm{mm}$ (in.): } \\
\hline Semimajor axis, $a$ & $1.3(0.05)$ & $1.8(0.07)$ & $2.3(0.09)$ \\
\hline Semiminor axis, $b$ & $0.16(0.006)$ & $0.22(0.009)$ & $0.28(0.011)$ \\
\hline \multicolumn{4}{|l|}{ Maximum shear stress values and depths: } \\
\hline$\tau_{o}, \mathrm{GPa}(\mathrm{ksi})$ & $0.343(49.8)$ & $0.472(68.5)$ & $0.601(87.2)$ \\
\hline$z_{o}, \mathrm{~mm}$ (in.) & $0.079(0.003)$ & $0.107(0.004)$ & $0.137(0.005)$ \\
\hline$\tau_{\max }, \mathrm{GPa}(\mathrm{ksi})$ & $0.459(66.6)$ & $0.644(93.4)$ & $0.814(118.1)$ \\
\hline$z_{o}, \operatorname{mm}$ (in.) & $0.114(0.005)$ & $0.140(0.006)$ & $0.191(0.008)$ \\
\hline$\sigma_{\mathrm{vm}}, \mathrm{GPa}(\mathrm{ksi})$ & $0.821(119.1)$ & $1.154(167.4)$ & $1.465(212.4)$ \\
\hline$z_{o}, \mathrm{~mm}$ (in.) & $0.114(0.005)$ & $0.140(0.006)$ & $0.191(0.008)$ \\
\hline $\begin{array}{l}\text { Relative lives for values if } n \text { from Eq. (9): } \\
\qquad n=9\end{array}$ & 153.94 & 8.76 & 1.0 \\
\hline$n=12$ & 825.01 & 18.06 & 1.0 \\
\hline
\end{tabular}

TABLE 3.-ASSUMED AND CALCULATED VALUES FOR LIFE ANALYSIS OF TABLE 4

\begin{tabular}{|c|c|c|c|c|c|c|c|}
\hline Parameter & $\begin{array}{l}\text { Weibull } \\
\text { Eq. (10) }\end{array}$ & $\begin{array}{l}\text { Lundberg- } \\
\text { Palmgren } \\
\text { Eq. (14) }\end{array}$ & \multicolumn{3}{|c|}{ Ioannides-Harris Eq. (25) } & \multicolumn{2}{|c|}{$\begin{array}{l}\text { Zaretsky } \\
\text { Eq. (29) }\end{array}$} \\
\hline $\begin{array}{l}\text { Critical shear stress, } \\
\text { GPa (ksi) }\end{array}$ & $\tau_{\max }$ & $\tau_{o}$ & $\tau_{0}$ & $\tau_{45}$ & $\sigma_{\mathrm{vm}}$ & $\tau_{45}$ & $\sigma_{\mathrm{vm}}$ \\
\hline Weibull slope, $e$ & 1.1 & 1.1 & 1.1 & 1.1 & 1.1 & 1.1 & 1.1 \\
\hline $\begin{array}{c}\text { Lundberg-Palmgren } \\
\text { parameters: } \\
\text { cle } \\
\text { h/e }\end{array}$ & 9.0 & $\begin{array}{l}9.3^{\mathrm{a}} \\
2.1^{\mathrm{a}}\end{array}$ & $\begin{array}{l}9.3 \\
2.1\end{array}$ & $\begin{array}{l}9.3 \\
2.1\end{array}$ & $\begin{array}{l}9.3 \\
2.1\end{array}$ & $9.0^{\mathrm{b}}$ & $9.0^{\mathrm{b}}$ \\
\hline $\begin{array}{l}\text { Shear fatigue- } \\
\quad \text { limiting stress, } \tau_{u}\end{array}$ & & 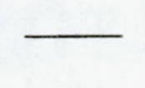 & $0.21(30)$ & $0.21(30)$ & $0.35(50)$ & & \\
\hline $\begin{array}{l}\text { Normalized material } \\
\text { constant, }{ }^{\mathrm{a}} A / l^{0.909}, \\
\text { N-m (lbf-in.) }\end{array}$ & $\begin{array}{r}2.6 \times 10^{74} \\
\left(5.8 \times 10^{42}\right)\end{array}$ & $\begin{array}{r}8.1 \times 10^{80} \\
\left(1.6 \times 10^{46}\right)\end{array}$ & $\begin{array}{c}0.58 \times 10^{39} \\
(11542)\end{array}$ & $\begin{array}{l}4.5 \times 10^{39} \\
(90356)\end{array}$ & $\begin{array}{l}2.5 \times 10^{39} \\
(49358)\end{array}$ & $\begin{array}{l}1.5 \times 10^{38} \\
(34056)\end{array}$ & $\begin{array}{l}1.3 \times 10^{36} \\
(28357)\end{array}$ \\
\hline $\begin{array}{l}\text { Stress-life exponent, } \\
\quad n \text { (Eq. (9)) }\end{array}$ & $10.8^{c}$ & 9.0 & $19.6^{\mathrm{C}}$ & $16.8^{c}$ & $15.1^{\mathrm{c}}$ & $10.8^{c}$ & $11.1^{\mathrm{c}}$ \\
\hline
\end{tabular}

${ }^{2}$ Calculated.

${ }^{b}$ Value of exponent $c$ where Lundberg-Palmgren parameter cle becomes cele.

${ }^{c}$ Calculated (refer to Table 4). 
TABLE 4.- COMPARISON OF RELATTVE LIFE FROM FOUR LIFE EQUATIONS

\begin{tabular}{|c|c|c|c|c|c|c|c|c|c|}
\hline \multirow[t]{3}{*}{$\begin{array}{l}\text { Maximum } \\
\text { Hertz stress, } \\
\text { GPa (ksi) }\end{array}$} & \multicolumn{2}{|c|}{$\begin{array}{c}\text { Relative lives } \\
\text { for values of } \\
n \text { from Eq. (9) }\end{array}$} & \multicolumn{7}{|c|}{ Relative theoretical lives } \\
\hline & \multirow[t]{2}{*}{$n=9$} & \multirow[t]{2}{*}{$n=12$} & \multirow{2}{*}{$\begin{array}{l}\text { Weibull } \\
\text { Eq. }(10)^{\mathrm{a}}\end{array}$} & \multirow{2}{*}{$\begin{array}{l}\text { Lundberg- } \\
\text { Palmgren } \\
\text { Eq. }(14)^{b}\end{array}$} & \multicolumn{3}{|c|}{ Ioannides-Harris Eq. (25) } & \multicolumn{2}{|c|}{ Zaretsky Eq. (29) } \\
\hline & & & & & $\begin{array}{c}\text { Based on } \\
\tau_{0}\end{array}$ & $\begin{array}{c}\text { Based on } \\
\tau_{45}\end{array}$ & $\begin{array}{c}\text { Based on } \\
\sigma_{\mathrm{vm}}\end{array}$ & $\begin{array}{l}\text { Based } \\
\text { on } \tau_{45} \\
\end{array}$ & $\begin{array}{l}\text { Based } \\
\text { on } \sigma_{\mathrm{vm}}\end{array}$ \\
\hline $\begin{array}{l}1.4(200) \\
1.9(275) \\
2.4(350)\end{array}$ & $\begin{array}{r}153.9 \\
8.8 \\
1.0\end{array}$ & $\begin{array}{r}825.0 \\
18.1 \\
1.0\end{array}$ & $\begin{array}{r}423.9 \\
13.6 \\
1.0\end{array}$ & $\begin{array}{r}154.7 \\
7.1 \\
1.0\end{array}$ & $\begin{array}{r}59477.8 \\
76.1 \\
1.0\end{array}$ & $\begin{array}{r}12112.0 \\
149.7 \\
1.0\end{array}$ & $\begin{array}{r}4643.0 \\
85.2 \\
1.0\end{array}$ & $\begin{array}{r}431.4 \\
11.7 \\
1.0\end{array}$ & $\begin{array}{r}495.6 \\
12.9 \\
1.0\end{array}$ \\
\hline $\begin{array}{l}\text { Calculated } \\
\text { value of } n\end{array}$ & 9.0 & 12.0 & $c_{10.8}$ & 9.0 & ${ }^{c} 19.6$ & $\mathrm{c}_{16.8}$ & ${ }^{c} 15.1$ & $c_{10.8}$ & ${ }^{c} 11.1$ \\
\hline
\end{tabular}

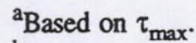

bBased on $\tau_{o}$.

'Determined between 1.4 and $2.4 \mathrm{GPa}$ (200 and $350 \mathrm{ksi})$.

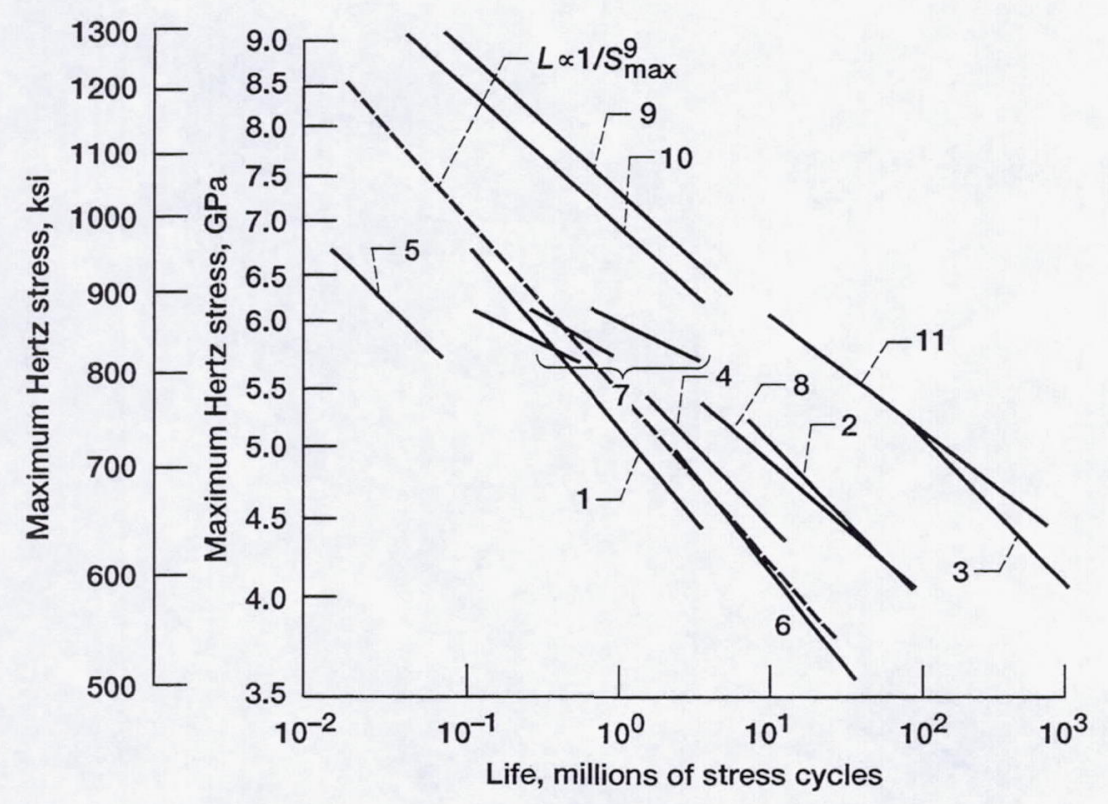

Figure 1.-Summary of published stress-life relation data for Hertzian contacts failing from rolling-element fatigue. (Refer to Table 1.) Ref. 9. 


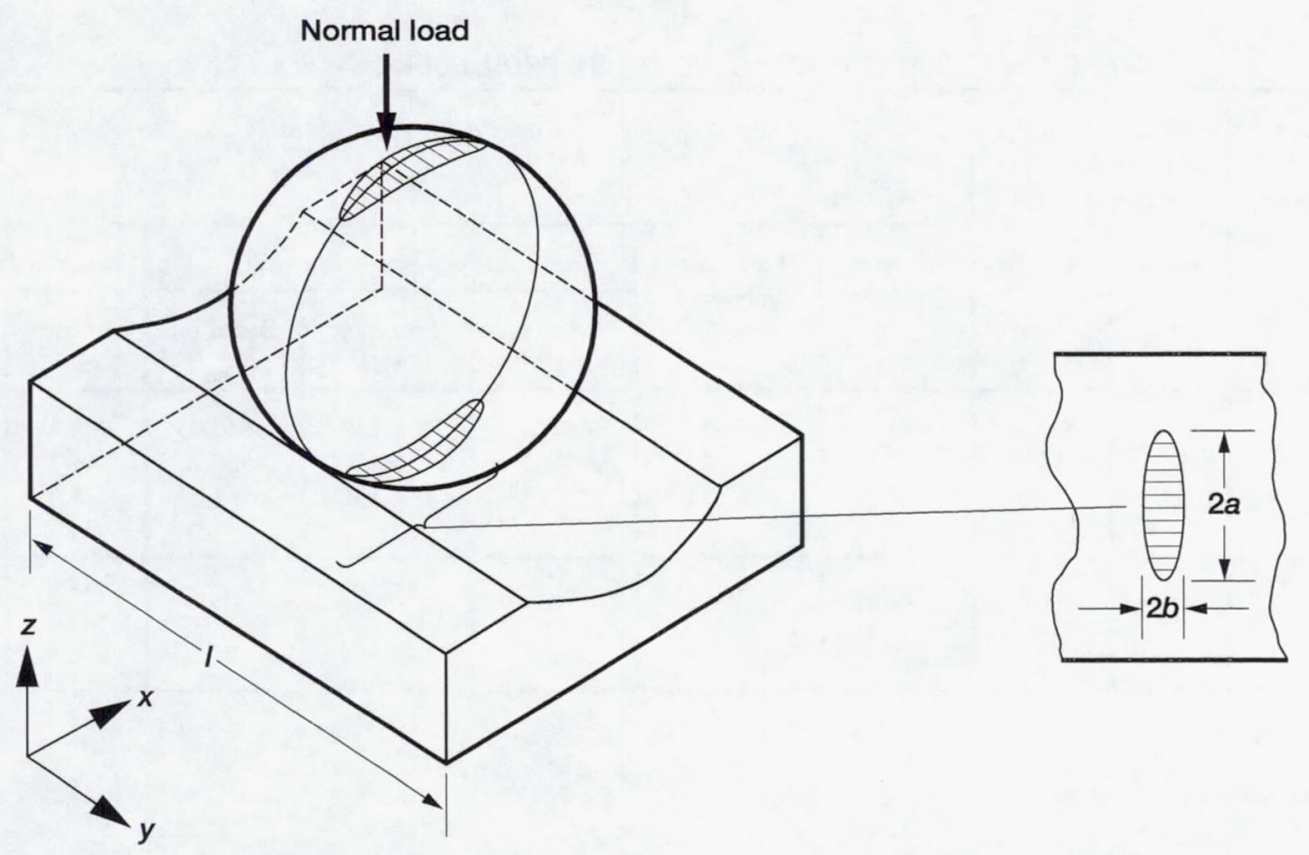

Figure 2.-Ball-race model.

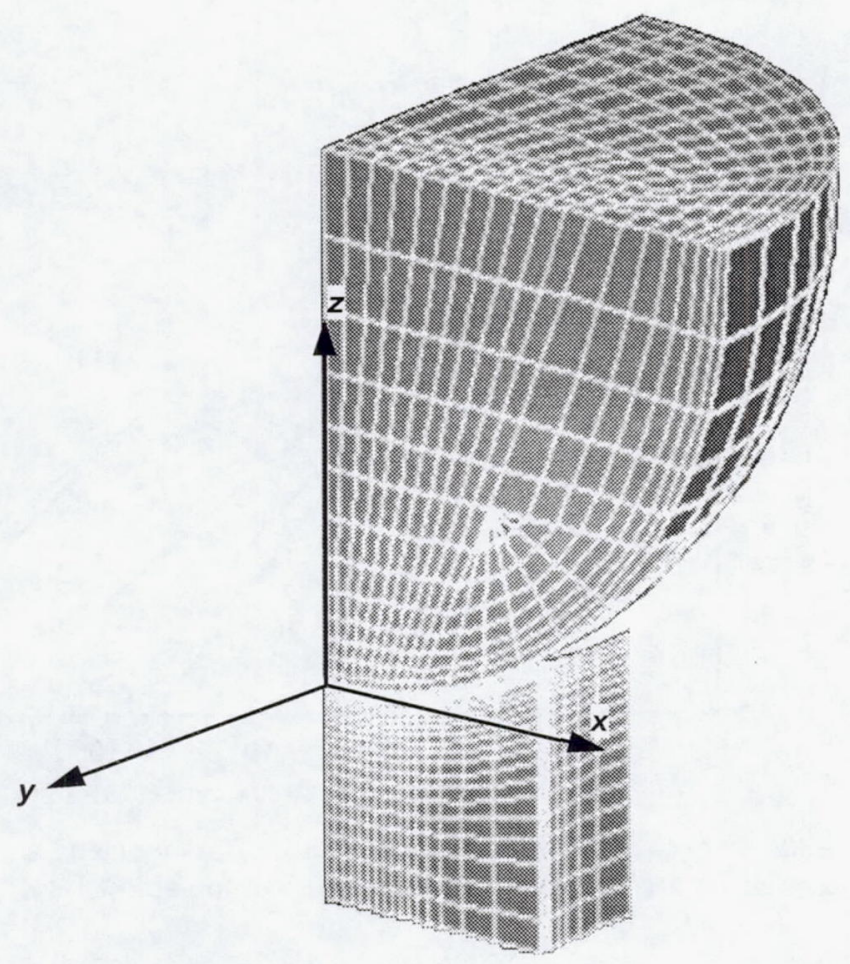

Figure 3.-Finite-element quarter symmetry ball-race model. 


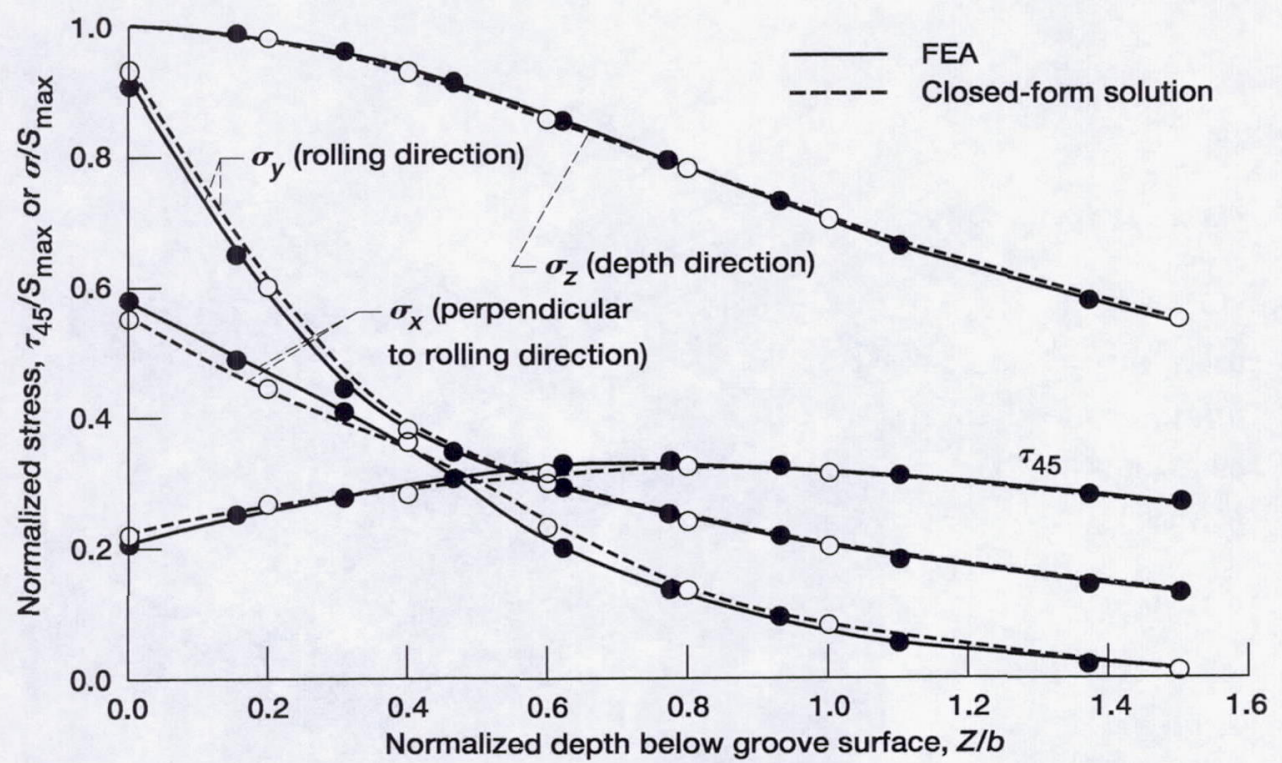

Figure 4.-Comparison of finite-element stress analysis (FEA) with closed-form solution for principal stresses and $\tau_{45}$ shear stress as a function of depth below groove surface (see Fig. 2). Ball diameter, $12.7 \mathrm{~mm}$ (0.5 in.); groove conformity, 52 percent; normal load, $623 \mathrm{~N}$ (140 lbf); maximum Hertz stress, 1.4 GPa (200 ksi); semimajor contact axis, a, $1.3 \mathrm{~mm}$ (0.05 in.); semiminor contact axis, $b, 0.16 \mathrm{~mm}$ ( $0.006 \mathrm{in}$.). 


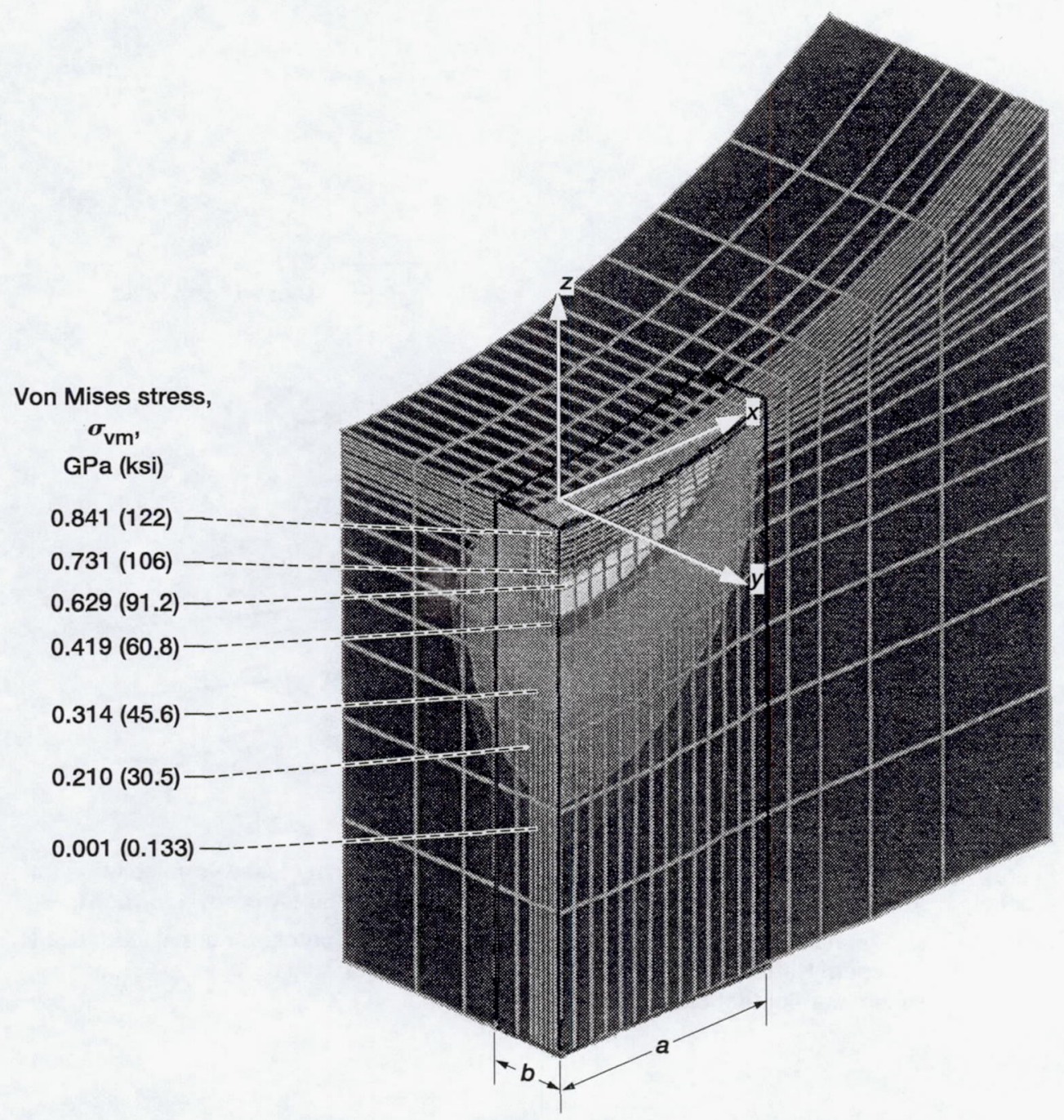

Figure 5.-Von Mises stress field in race groove for Hertzian contact of ball on groove (see Fig. 2). Ball diameter, $12.7 \mathrm{~mm}$ ( $0.5 \mathrm{in}$.); groove conformity, 52 percent; normal load, $623 \mathrm{~N}$ (140 lbf); maximum Hertz stress, 1.4 GPa (200 ksi); semimajor contact axis, a, $1.3 \mathrm{~mm}$ (0.05 in.); semiminor contact axis, $b, 0.16 \mathrm{~mm}$ (0.006 in.). 
In-plane

shear stress,

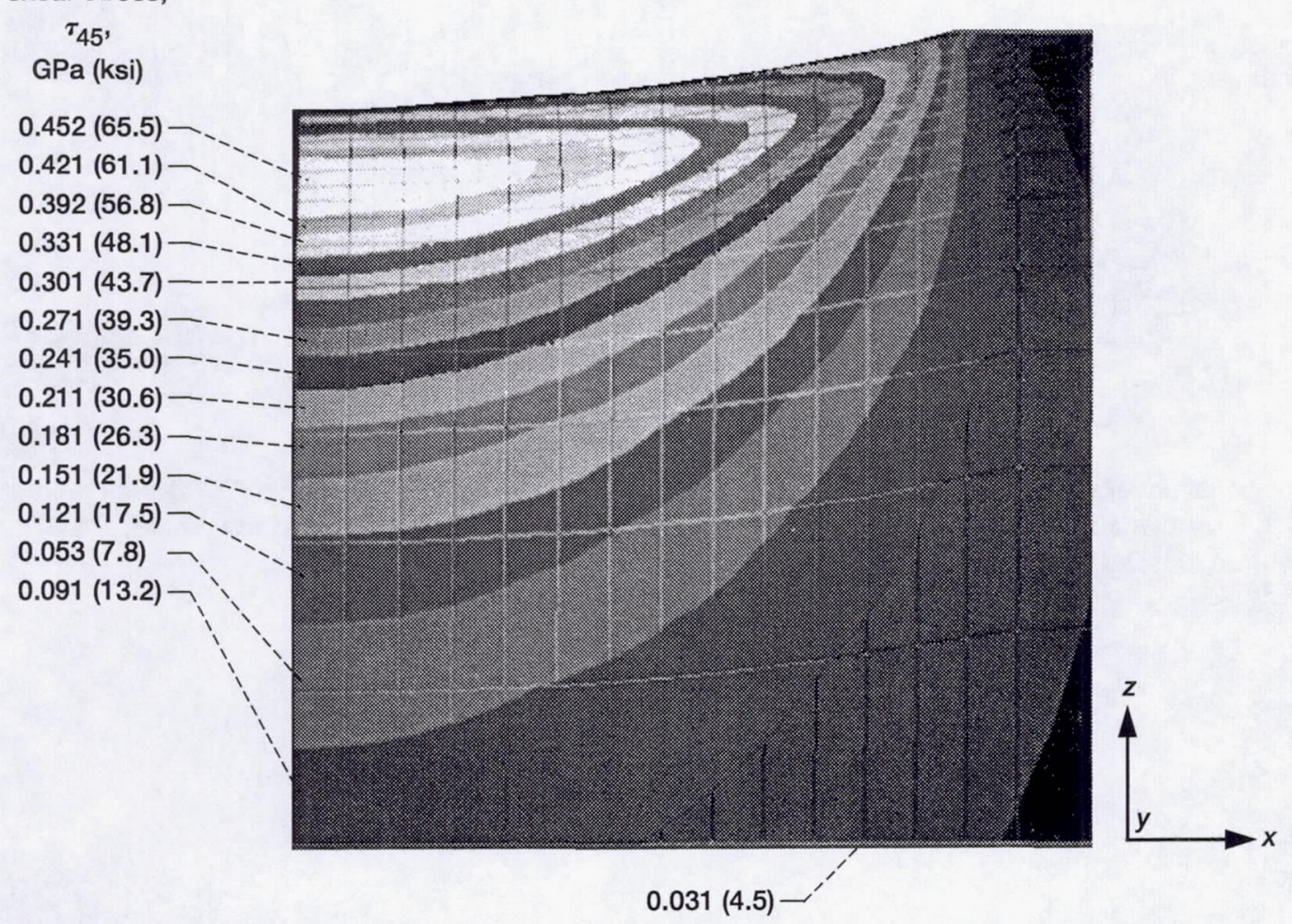

Figure 6.-In-plane shear stress in race groove for Hertzian contact of ball on groove (see Fig. 2).

Ball diameter, $12.7 \mathrm{~mm}$ (0.5 in.); groove conformity, 52 percent; normal load, $623 \mathrm{~N}$ (140 lbf); maximum Hertz stress, $1.4 \mathrm{GPa}$ (200 ksi); semimajor contact axis, a, $1.3 \mathrm{~mm}$ (0.05 in.); semiminor contact axis, $b$, $0.16 \mathrm{~mm}$ (0.006 in.). 


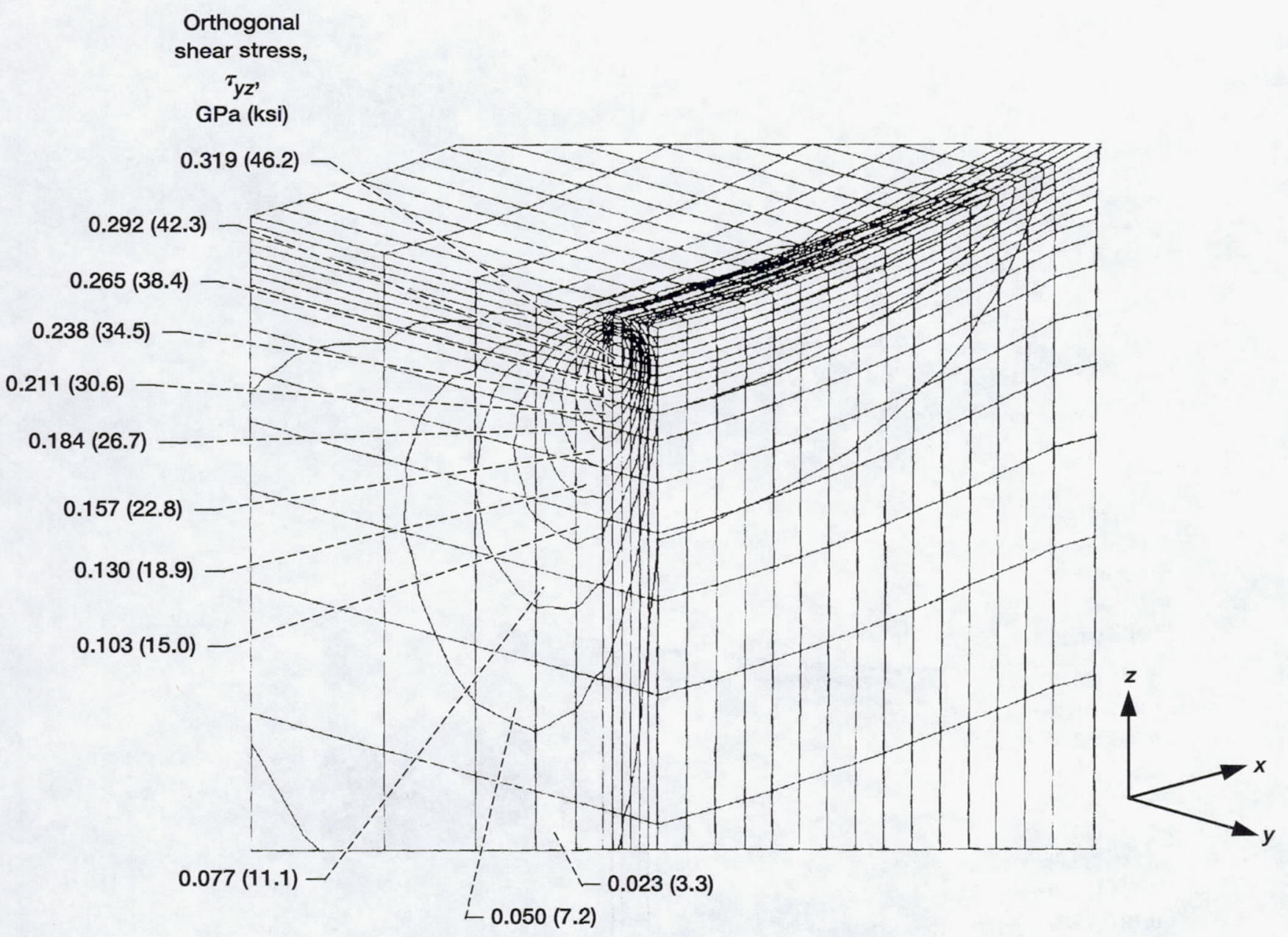

Figure 7.-Orthogonal shear stress in race groove for Hertzian contact of ball on groove (see Fig. 2). Ball diameter, $12.7 \mathrm{~mm}$ (0.5 in.); groove conformity, 52 percent; normal load, $623 \mathrm{~N}$ (140 lbf); maximum Hertz stress, $1.4 \mathrm{GPa}$ (200 ksi); semimajor contact axis, a, $1.3 \mathrm{~mm}$ (0.05 in.); semiminor contact axis, b, $0.16 \mathrm{~mm}$ (0.006 in.).

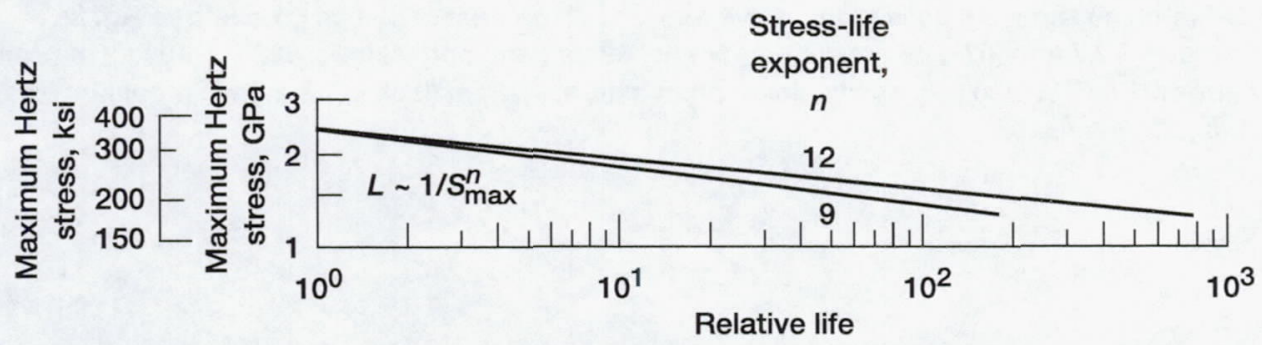

Figure 8.-Effect of stress-life exponent and maximum Hertz stress on rolling-element fatigue life of nonconforming race groove. 
Public reporting burden for this collection of information is estimated to average 1 hour per response, including the time for reviewing instructions, searching existing data sources, gathering and inter send comments regarding this burden estimate or any other aspect of this Davis Highway, Suite 1204, Arlington, VA 22202-4302, and to the Office of Management and Budget, Paperwork Reduction Project (0704-0188), Washington, DC 20503.

\begin{tabular}{l|l} 
1. AGENCY USE ONLY (Leave blank) & 2. REPORT DATE
\end{tabular}

\section{TITLE AND SUBTITLE}

April 1995

3. REPORT TYPE AND DATES COVERED

Technical Memorandum

Comparison of Life Theories for Rolling-Element Bearings

5. FUNDING NUMBERS

6. AUTHOR(S)

WU-505-63-5B

Erwin V. Zaretsky, Joseph V. Poplawski, and Steven M. Peters

7. PERFORMING ORGANIZATION NAME(S) AND ADDRESS(ES)

National Aeronautics and Space Administration

Lewis Research Center

Cleveland, Ohio 44135-3191

8. PERFORMING ORGANIZATION REPORT NUMBER

E-9473

9. SPONSORING/MONITORING AGENCY NAME(S) AND ADDRESS(ES)

10. SPONSORING/MONITORING AGENCY REPORT NUMBER

National Aeronautics and Space Administration

Washington, D.C. $20546-0001$

NASA TM-106585

\section{SUPPLEMENTARY NOTES}

Prepared for the Annual Meeting sponsored by the Society of Tribologists and Lubrication Engineers, Chicago, Illinois, May 14-19, 1995. Erwin V. Zaretsky, NASA Lewis Research Center; Joseph V. Poplawski and Steven M. Peters, J.V. Poplawski \& Associates, Bethlehem, Pennsylvania. Responsible person, Erwin V. Zaretsky, organization code 5200, (216) 433-3241.

12a. DISTRIBUTION/AVAILABILITY STATEMENT

12b. DISTRIBUTION CODE

Unclassified - Unlimited

Subject Category 37

This publication is available from the NASA Center for Aerospace Information, (301) 621-0390.

13. ABSTRACT (Maximum 200 words)

Nearly five decades have passed since G. Lundberg and A. Palmgren published their life theory in 1947 and 1952 and it was adopted as an ANSI/ABMA and ISO standard in 1950 and 1953. Subsequently, many variations and deviations from their life theory have been proposed, the most recent being that of E. Ioannides and T.A. Harris in 1985. This paper presents a critical analysis comparing the results of different life theories and discussing their implications in the design and analysis of rolling-element bearings. Variations in the stress-life relation and in the critical stress related to bearing life are discussed using stress fields obtained from three-dimensional, finite-element analysis of a ball in a nonconforming race under varying load. The results showed that for a ninth power stress-life exponent the Lundberg-Palmgren theory best predicts life as exhibited by most air-melted bearing steels. For a 12th power relation reflected by modern bearing steels, a Zaretsky-modified Weibull equation is superior. The assumption of a fatigue-limiting stress distorts the stress-life exponent and overpredicts life.

\begin{tabular}{|c|c|c|}
\hline $\begin{array}{c}\text { 14. SUBJECT TERMS } \\
\text { Ball bearings; Life prediction; Reliability }\end{array}$ & $\begin{array}{c}\text { OBSTRACT } \\
\text { Unclassified }\end{array}$ \\
\hline $\begin{array}{c}\text { 17. SECURITY CLASSIFICATION } \\
\text { OF REPORT } \\
\text { Unclassified }\end{array}$ & $\begin{array}{c}\text { 18. SECURITY CLASSIFICATION } \\
\text { OF THIS PAGE } \\
\text { Unclassified }\end{array}$ & $\begin{array}{c}\text { 19. SECURITY CLASSIFION } \\
\text { OF }\end{array}$ \\
\hline
\end{tabular}

